\title{
The Elbasanisht and Literary Committee of Shkodra
}

\author{
Manola Myrta \\ Ph. D. Candidate, Faculty of Education \\ "Aleksander Moisiu "University, Durres, Albania. \\ manola.myrta@yahoo.com
}

\section{Doi:10.5901/jesr.2013.v3n7p539}

\begin{abstract}
There are various ways of creating a national standard variation of a language. Highly significant roles in its creation, among others are the social factors such as: the general historical background, social development etc. Elbasanisht as a part of Gheg dialect has been discussed for a long time to be the standard Albanian. In this context, it is important to know when the first idea of Elbasanisht as a standard language was. Which was that institution that made such a decision for the first time? On the basis of which criteria was Elbasanisht selected as a representative language variation of the Albanian people? Why did this decision fail?These questions constitute the basis of this study which aims to shed light, to reflect and present the role and importance of the literary Committee of Shkodra (1916-1917), the issue of creating the standard Albanian. The paper will also treat by whom and how was the idea of selecting Elbasanisht as the common language variation disposed; the linguistic criteria which determined the selection of Elbasanisht; the Albanian outstanding linguists who supported this decision. The paper might help all linguists who deal with the study and formation of the standard languages and to all those interested in creating the standard Albanian.
\end{abstract}

Keywords: standard language, Literary Committee of Shkodra, Elbasanisht, criteria supporters.

\section{Introduction}

The formation of standard Albanian language, as the most elaborated variant of Albanian language, has been a long process that began during the centuries XI-XIII, but its elaboration entered in a new period of the century XIX, during the National Renaissance. This process is closely related to social-historical changes that happened in our place during different periods. At this long itinerary, the Literary Committee of Shkodra took a very important step for the unification of the standard Albanian language.

This Committee of writers and linguists, created to help in the formation of a common literary variant, through the union of the two literary variants in use, assessed the middle literary variant, local language of Elbasan, as a bridge between Gheg and Tosk dialects. The Committee also determined some rules for the orthography of this variant, that affected in the unification of written Albanian language.

\section{Comitee of Shkodra, as the institution which contribute to the foundation of the future standard Albanian}

The Literary Committee of Shkodra is a very valuable institution that is related to the setting of the bases for the process of the creation of standard Albanian language. It is founded on 1 September 1916 and it represents a key problem for the Albanian language and Albanian nation. The most important purpose of the Committee was the orthography issue and the determination of a literary variant in which will be supported the standard Albanian language. At that time, this issue consisted as a necessity for the Albanian nation, and for the preservation of Albanian's identity, despite unfavorable social conditions.

The Committee was concentrated in some problems, but starting from the great and important duties that assumed, it exceeds the dimensions of a committee, and can be compared to the literary and educational congress held in Albania. During the development of the Literary Committee, obviously stand out some important characteristics:

- The high rank of its organisators. In this committee participated some representers, patriots and personalities of the national life and culture as L.Gurakuqi, Gjergj Pekmezi, Ndre Mjeda, Mati Logoreci, Sotir Peci, Hilë Mosi, Aleksandër Xhuvani, Gjergj Fishta, Luigj Naraçi, Ndue Paluca, Ambros Marlaskaj, Rajko Nachtigal dhe Maxsimillian Lambertz.

- Objections and major tasks that committee assumed laid for solution as the important decisions that took by 
using political circumstances, the albanian common standard time without disconnecting this major issue of nation with orthographic and above all taking into consideration approachment of the task of bringing both literary variants .

- The splendid organization of committee and its activities.

As it could be obviously identified the composition at Committee was quiet heterogeneous; the greater role-played the progressist and democratic elements with Luigj Gurakuqi on the top. Its most important decisions aimed the unification of orthography, which it was signed as a link of national literary language. One of the issues that was discussed at Committee and it was very important related properly to the creation of union Albanian language. Achieving such a purpose conditioned by different factors as political social, cultural and educational factors. This issue was rightly considered as a node from the national renaissance time (Osmani, 2002 p.59).

The issue of a common language creation first opened to the collection on 11 December 1916 and consisted in itself when issue of fundamental importance. The chief of the Committee was Gjergj Pegmezi and in his speech, he said: " There is no doubt that every one of us knows very well that nowadays orthography it is not our first goal. It is known that where there is no language there is no orthography. The common language is what we lack and need necessarily and obviously all of us want it "(Osmani, 2002, p.59).

According to him the problem should be treated in two plans at the theoritical and practical, and introduce three alternatives which may rely on start working.

1. Taken based on dialect and from this to become a scheme, which after will be dressed and will be adorned with the phraseology and lexicology of alll the other dialects.

2. To remain written dialects close to each other bringing them down and spread in any way, in other parts of Albania to become rubbing which undoubtedly would cause that flame which we want (Osmani, 2002 p.60) .

3. To be considered only tipical changes between the two dialects refering its one language. "I want to say sing what the language has done in these cases to go after it (Osmani, 2002, p. 60). Meanwhile, since Luigj Gurakuqi played an important role to the committee who asked to be chosen "a dialect to be as a connecting bridge "(Osmani, 2002, p.60).

In fact, when he was expressed that way he was refered to local language of Elbasan that according to him should be the base on this must be built the standard Albanian language. However, although was supporter of this idea he was introduced more rational when he expressed that did not like the local language of Elbasan as it was. So, according to him should have been found middle forms with improvements to put them in common language (Osmani, 2002, p.60).

On the other side, Pekmezi did not appear enthusiastic about this solution because it needed specialists and a long time for this to be achieved. He proposed for this to be called an albanologist that was optained by studying the Albanian language and to be sent into Elbasan to study all the forms of this speaking. He between three languages liked to remain both existing dialects. Pekmezi believed that every beginning is difficult and should be thought in cold blood. "Better slowly and less work, but qualitive that fastly, much work but full of mistakes (Osmani, 2002, p.60).

There were included in this discussion many other members, Fishta one of the members with enough influence at the committee who didn't contradict such an idea and asked that common language shouldn't last anymore this issue which must be used. He was convinced and liked fully to consider the Elbasan's dialect (Osmani, p. 60).

If we would make a summary of attitude and opinions expressed at the Committee regarding the problem of creating a literary common language and its dialectal base, will be clearly distinguished in two main groups:

- One party thought to be held a literary bilingual system, Gheg dialect based on local language of Shkodra and literary dialect of Tosk.

- Luigj Gurakuqi who proposed the dialect of Central Albania supports the other opinion or local language of Elbasan to put based on literary Albanian language.

The discussions between the partied were harsh and continued for a long time. Meanwhile, it should be confirmed that in this line of discussions were not included only Albanian researchers and linguistics. Visibly were presented the transparent and clear attitude of foreign albanologies who were included in determinations issue of literary Albanian language.

Related to this problem, Rajko Nachtigal holds the position that the choice of one by the main dialects as a base of common language did not seem possible due to provincial and religious disunity of Albanians, as the use of two dialectal bases. In north Gheg, in south Tosk creating a natural approach road till to a definitive conclusion which will last this for a long time .

An artificial production of phonetic and morphological of Tosk and Gheg dialectal characteristics. It's not a priority to be accepted by the reason of its arbitrary nature (Ismaili 2005, p.71). Nachtigal proposed to be considered the central 
dialect identified with the local language of Elbasan, because due to central geographical position which is understood by all (Ismaili 2005, p.71).

In this stream of thinking was the schollar Gustav Vajgand who confirmed south Gheg dialect which must not be considered as the mixed dialect Tosk and Gheg, but in its phonetic condition summarizes all Gheg characteristics. It is not understandable only for Albanians but even the dialect can be learned more easily. The simplicity of name and pronoun bending against small number of verbal traits, all these are enough relief to learn Gheg against Tosk (Ismaili, 2005, p.71).

German researcher George Von Hahn described as the father of albanology discussing the division of albanian dialect has indicated that the future of our common language must be requested there where couldn't be done the final separation between Gheg and Tosk, where elements of both main dialects approach and mix to each-other (Ismaili, 2005, p.71). Its attitude lets you know that this albanologist was for literary Elbasan's local language.

After numerous scientific debates, it was decided animously and it was approved Gurakuqi's thesis for the selection of Elbasan's dialect as a writing language. Gurakuqi proposed his opinion through this formula. Being that Elbasan's dialect, according to syntax point of view, is like a bridge between Gheg and Tosk, must be chosen as a writing language with orthography rules that seems to us right and rational. Giving this decision, the Literery Committee should keep in mind the duty, to become neccesary research, to find a middle form, which approaches the dialectal changes of both dialects (Çeliku, 2002, p.25).

This thesis he managed to formulate and presented to the Committee, given the fact that he was good expert of Elbasan'slocal language speaking, of writing traditions and Normal School achievement, director of which he has been himself and simultaneously expert of contributions by Elhanan's intellectuals to linguistics.

There were great discussions about in which pieces of Kristoforidhi should rely on linguistics to create the common language, discussions which toook place the day after, on 12 December 1916. Specially it was claimed that the debates were held for the new testament of Kristoforidhi, the saint history supporter of which was Aleksander Xhuvani as about the grammatic of southern Gheg dialect supported in Durres, Tirana and Elbasan speaking ( 1913 ) of G.Vajgand .

Well as it seems, was not asked an empirical solution but scientific and reasonable. So was called as a correspondent of Committee Elbasan's philologist, Aleksander Xhuvani, to help in the improvement of standard language selection. It was thought that after start working Xhuvani, to be required the asistance of foreign albanologist for studies in areas where it was spoken. For that, reason was sent a linguistic expedition in Elbasan for three weeks composed by Gjergj Pekmezi, Ndre Mjeda and Rajko Nahtigal, at that time professor at the University of Austria Gracy.

The researches in the Central Albania were realized for a period for about two and a half months (15 March-30 May 1917).

The achievement of each group was presented in Literary Committee in order to become a summary and detailed analysis of linguistic. Although the problem quiet delicate, this issue was discussed without necessary attention and had its echo in all intellectual forces. What were the reasons for the proposal and selection of Elbasan's local language as a common language for all Albanians? The selection of Elbasan's local language as a writing one and it is setting up in the foundation of common oficial language, does not represent a spontaneous solution. This speaking fulfilled truly some basic conditions in which were based the decision of Shkodra's literary committee. Among them, is worth mentioning:

1. Elbasanisht was a Gheg talk of common traits with north Gheg and Tosk. As Gurakuqi and Xhuvani said, it was a bridge between the Gheg and Tosk .

2. Elbasanisht was a Gheg talk with written traditions without dialect dismissals, this tradition coincide in many features more with Tosk than north Gheg.

3. Elbasanisht as a sub variant of an important economic and cultural centre offer the writing tradition of notable figures, which were very important in the study of Albanian, as well as its practical use,. This tradition was led by the father of the Albanian language Kostandin Kristoforidhi, whose authoritative role as the first application of the dialects approaching in writing process. The role of scripture northern classical authors, significantly contributed to the decision taken by the authorities in Shkodra Literary Committee.

The writing tradition of Elbasanisht is early and wide. We can mention here the religious translations of Kristoforidhi, his "Abetare shqip" published in 1872, Kostandinopol, "The grammar" which has information for southern Gheg and Elbasanisht etc. It should be noted that the enrichment of this tradition from "Normalja e Elbasanit" (which was a noted school), which drafted and published textbooks and materials for students, teachers and language courses, some grammar and reading books and publications of various sciences, operating at the same time as lab text of use concrete Elbasanisht. In the recognition of Elasanisht played an important role the work of outstanding Albanologist Gustav Vajgand. 
The resolution of standard Albanian language constituted one of the goals of Committee, as another important aspect was the spelling. The Alphabet of Manastiri Congress opened the way towards unifying the phonemic system of written language; this solution got a solid character and became a true policy in Shkodra Literary Committee.

During its sessions determined the following general rules:

- $\quad$ To be preserved unstressed -ë- in written words

- $\quad$ not to be reflected graphically the quantity

- to write the full diphthongs

- the limited-use nasal sign

- To write and pronounce unassimilated the consonants groups: $m b, n d, n g j$, these are almost features of Gheg.

These decisions were historical and had paved the way of final solution to the problem. B.Beci claims: "They have been the main drivers towards the approach of the written language of both basic variants of written Albanian, and not as often has been stated approaching two Albanian dialects" (Beci, 1998).

What remains to be resolved after these decisions related to what can be called "intermediate choice " (Beci, 1998): hëna ose hana (Mondey); dimër ose dimën( winter); kam punuar (have worked), për të punuar( to work), i punuar ose kam punue (worked),; mësues ose mësonjës ( teacher ) that actually were the main distinctive features of the both Albanian dialects. So:

- The presence of stressed vowel ë in the southern dialect and its lack in the northern one: ã in Gheg and ë (< ã) in Tosk.

- The presence of differences phenomena in the southern dialect and its lack in the northern dialect, for Gheg dimën (winter) and in Tosk dimër (<dimën).

- The presence of vowel group ua in Tosk and ue vowel group in Gheg.

- The presence of infinitive in Geg and its lack in Tosk.

Meanwhile, the position of the two other features like the presence of opposition by length and by nasality in Gheg and in their lack in Tosk, was resolved through decisions of Shkodra Literary Committee, which played an important role to join in literary writing both Albanian variants.

As it was mentioned in the above discussion, decisions of Literary Committee gave a big push forward the establishment of a common standard language and its orthography. Especially, in Elbasan these decisions had a large impact. They embraced and began to be executed by different authors in their publications. It is worth noting at this point A.Xhuvani said in "Librin e Gjuhës" ("grammar") for the third primary grade school, published in 1919, in which the author's preface notes:

"The in the grammar boundaries and orthography, I consider to protect the grammar boundaries as orthography rules , which had been founded in Shkodra Literary Committee , the author adds:" As for the other orthographic linguistic traits, such as in the way of writing infinitive and adjectives etc. The work that had did not been done even in that Committee, I followed a medium track in using Tosk traits but not leaving out of the fundamental principle of Committee that language orthography will be based on the dialect of Elbasan ". (Çeliku, 2002, p. 128-129).

Let us also mention another author from Elbasan: Dhimitër N.Paparisto (director of Shkolla Normale) who in his book "Reading for elementary school", published in 1919, Elbasan says in the preface:

"The lack of reading books and Literary Committee decision of Shkodra that Elbasan dialect should be used in school books, was the purpose of writing this book ...." (Çeliku, 2002, p. 128-129)

What should be noted is the fact that in the writing tradition of Elbasanisht with a conscious effort to approach literary Elbasanisht with Tosk, had been started by Kristoforidhi. The same had done Dhimitër Shuteriqi in his ABC published in Manastiri in 1911, five years before the Literary Committee. Even its title, "ABC in Albanian common language "expresses the author's attitude to the use of a common language.

Let us treat some more concrete language phenomenon that endears the author' language (Elbasanisht) with Tosk:

- It does not mark the stressed nasal vowels: asht( is), ban( do), vena( go ).

- It saves as in Tosk groups mb, nd, ng, kombin (nation), krymbi (worn), mban(hold), u mbarua(finished), këndoni (sing).

- It writes complete as Tosk two vowels: ie, ye: qiell,(sky), diell( sun), krye(top), fyelli (pipe). top, pipe.

- It uses the two vowels of Tosk instead of $u$ (u) of Elbasanisht: grua (woman), muaj (month), duar( hands), 
kuaj( horses), u mbarua( finished), u mbulua( covered), shkruajmë( write).

- It is near parotasizuara traits: gjarpën-i (snake), dreni (reindeer), freni (brake), dimëni (winter), ullini (olive), using partial with Elbasanisht endings or rotacizuara.: blemun (bought), Bamut(done), Lemu(lemon). Adjectives like, $i$ tërbuar (furious) etc.

- It uses as Tosk the vowel in the middle and the end of words: shtëpia( house), thërrime(crumb), sëmundë(illness); bukë (bread), i mire (good), i forte (strong), e vërtetë(true), të shëndoshë( fat), të bardhë(white); katundarë( villagers); këndon (sing), shkruajmë (write), banojmë (live).

- The author consider as long vowels only the ending stressed vowels in feminine nouns adding an ë after them, such as : thellësië (depth), shtëpiën (Mouse), (muret) e shtëpiës( the walls of house) ,pleqëniën(elderly), ngrohtësinë (warmness), but does not result the long vowel when it is followed by another vowel : rakia(brandy), shiu (rain), njeriu (man), hardhia (vine).

As in the Tosk, vocal vowels are deafen at the end of word: shtek (path), pëllump (pigeon), komp (nation), funt (skirt), i math (big) etc.

- Use regular ending $n j$ to a present tense of verbs and plural suffix- $-n j$ to the plural names etc.: besonj (believe), ullinj (olives), mësonjës (teacher), shëronjësi (doctor); të mëdhenj (big).

Perhaps we have discussed a lot about the description of the linguistic features of $A B C$, but we have done it because we find realized in practice the vast majority of "Rules of orthography collection written in Albanian language", established by Literary Committee five years later (1917) (Çeliku, 2002, p. 129).

If we return to the practice followed by Elbasan authors based on the decisions taken at the Committee, we must say that:

- They practice the historical and morphological criteria, especially in the writing of the unstressed ë-.

- They do not reflect the nasality and quantity of vowels in writing stressed vowels.

- They save groups $m b, n d, n g$.

- They save two vowels ie, ue, ye etc..

This shows that Elbasan had had an early writing tradition in the conscious approach of Gheg (mainly Elbasanisht) with Tosk and being close to "rules of orthography in the written collection of Albanian language". In the writing tradition of Elbasanisht and Tosk, putting in their bases the dialect of Elbasan with some modifications, it has been scientific and responding to the linguistic reality.

Decisions taken in Literary Committee to unify the spelling of Albanian national literary language had echoed across the country. In addition, the Educational Congress of Lushnja passed them in 1920.

However, if we look later the history associated with the creation of standard Albanian, should be acknowledged that, despite the decision of the Committee, selecting Elbasanisht as the variant on which to rely standard Albanian language, despite all the efforts and dedication Elbasan authors, this did not occur completely. Social and political changes in Albania and the consequent decisions of this nature (after liberation), brought a new era and they gave the standard Albanian another face.

\section{Conclusions}

Literary Committee of Shkodra with its decisions carried further unification of Albanian standard language and its spelling. It carried out the Renaissance conscious intention to bring the two written dialect literary variants to the unification of written Albanian. It developed orthography rules, which serve as the basis for subsequent orthography, compiled extensive lists of words, where the rules were applied, it paid attention drafting technical terms, terminology principles (justice, the administration, and school), it paid attention to the treatment of school textbook etc.

Literary Committee of Shkodra due to its purposes and decisions that approach two variants of literary writing marks a major step in the unification of Albanian standard language and it is ranked near the Manastiri Congress, Elbasan Congress and other similar Congresses. Obviously if the term referred to the standard Albanian, it is inevitably associated direcly to Shkodra Literary Committee.

\section{References}

Beci, B.,Rreth tipareve karakteristike të dy dialekteve të shqipes, në "SF", 2, Tiranë, 1970

Çeliku, M., Çështje të shqipes standarde, Tiranë, 2002.

Gjurmime albanologjike, seria e shkencave filologjike 28-29, Instituti albanologjik i Prishtinës, Prishtinë 2002.

Ismajli, R., Gjuhë standarde dhe histori identitetesh, Tiranë, 2005. 
Konferenca shkencore kombëtare dhe bota shqiptare sot, Akademia e Shkencave e Shqipërisë, Instituti i Gjuhësisë dhe i letërsisë, Tiranë, 20-21 nëntor 1992.

Kostallari, A., Gjuha e sotme letrare shqipe dhe disa probleme themelore të drejtshkrimit, Tiranë, 1973.

Lloshi, Xh., Kristoforidhi përmes dokumentimit, Tiranë 2005.

Ortografia e gjuhës shqipe, Instituti i shkencave, Tiranë, 1951.

Osmani, T., Ngjarje me rëndësi e kulturës sonë-Komisia Letrare Shqipe në Shkodër (1916-1917), në

Samara, M., Formimi i gjuhës letrare kombëtare shqipe, Tiranë, 1989.

Xhuvani, A., Studime gjuhësore, Tiranë, 1956.

Beci, B., Rreth disa pikëpamjeve të shprehura në revistën "Studime filologjike", 1-2, 1998 (burim nga interneti). 